\title{
文心雕龍全文資料庫簡介
}

\section{The Literary Mind and the Carving of Dragons Full-text Database: an Introduction}

\author{
王莉 Wang $L i$
}

DOI: http://dx.doi.org/10.7359/825-2017-wang

\section{摘要}

《文心雕龍》, 是中國第一部系統文藝理論巨著, 也是一部理論批評著作, 2000 年4月, 鎮江《文心雕龍》資料中心在鎮江市圖書館掛牌成立。資料中心積極搜集各個時期發表的 《文心雕龍》研究論文和專著, 至今已收集到論文 3500 餘篇。本文以《文心雕龍》電子資 料庫為基礎, 梳理1909-2006年論文的類型及數量, 以展示《文心雕龍》的發展脈絡。

關鍵字: 文心雕龍, 研究, 論文, 資料庫, 統計。

\section{ABstract}

Liu Xie's Wenxin diaolong (The Literary Mind and the Carving of Dragons) is China's first systematic and monumental work on literary theory and criticism, still standing as a milestone in the field. In April 2000, the "Zhenjiang Wenxin diaolong Data Center" was established in the Zhenjiang City Library. The Data Center actively collects research papers and monographs about Liu Xie's masterpiece, from various periods. To date, the Center has already collected more than 3500 papers. This paper is based on the electronic database of the Wenxin diaolong and illustrates the varieties and the number of papers collected from 1909 to 2006 . The aim of this paper is to show the branching development of the critical studies on the Wenxin diaolong.

Keywords: Wenxin diaolong, research, papers, database, statistics. 


\section{一、資料庫建立背景介紹}

2000年4月3日, 中國・鎮江《文心雕龍》資料中心在鎮江市圖書館掛牌成立。兩年後，由 中國文心雕龍學會和鎮江市人民政府攜手將這個中心提升為 “中國文心雕龍資料中心”。 資料中心積極搜集各個時期發表的文心雕龍研究論文和專著, 至今已收集到論文3500餘 篇, 1990年以前的收藏率達95\%, 1990年以來的收藏率達100\%, 專著240餘種, 是已 出版總量的百分之九十還多。另外還藏有一批港臺地區的論文與專著, 是全國乃至全世界 規模最大、資料最全的《文心雕龍》專題資料庫。

自2003年起, 鎮江市圖書館成立專門研究小組, 開始對資料中心所藏文心雕龍論文及 專著進行數位化，建設全文資料庫。目前 “文心雕龍全文資料庫單機版” 終於製作完成。收 入著名專家、學者的論文3509篇, 張少康教授的論文33篇, 時間跨度從20世紀初至今, 基 本包含了這一百餘年間出版的文心雕龍論文和部分專著。

二、從1909-1949年 (近代) 論文庫簡介

1909-1949年共搜集論文64篇, 發表在《華文學報》、《南開週刊》、《華國月刊》、《文學 月刊》、等 45 種刊物上。

(1) 1909-1949部分年份論文資料統計表

\begin{tabular}{cccccccccc}
\hline 年份 & 1919 & 1925 & 1926 & 1927 & 1936 & 1937 & 1941 & 1944 & 1945 \\
\hline 數量 & 3 & 8 & 5 & 5 & 5 & 9 & 6 & 4 & 7 \\
\hline
\end{tabular}

(一)1909-1949年收錄的論文主要包括兩方面內容

一、對《文心雕龍》各篇的述義、箋注、評論等內容。如1919年-文心雕龍附會篇評: 一文心 雕龍誇飾篇評、一文心雕龍答記誇飾篇評。

1936-文心雕龍時序篇述義

1949-文心雕龍論說篇述義

1938-文心雕龍隱秀篇2箋注

\section{二、從1956-1977年論文庫介紹}

此期間共收錄論文236篇, 收錄的論文主要包括:

（一)、劉务思的文學主張、世界觀、文學觀論、創作論、文體論、風骨論、二元論的哲學思 想以及文學批評的理論與實踐等內容。

(二)、《文心雕龍》的選擇《定勢》、《風骨》、《神思》、《體性》、《通變》、《情采》、 《比興》、《物色》的釋義等。 
(2) 1956-1977年部分年份論文數量統計表

\begin{tabular}{ccccccccc}
\hline 年份 & 1957 & 1958 & 1959 & 1960 & 1961 & 1962 & 1963 & 1975 \\
\hline 數量 & 8 & 4 & 10 & 6 & 55 & 94 & 31 & 8 \\
\hline
\end{tabular}

1957-試論劉劦思文學批評的現實性

一答毛任秋 “關於劉劦思的文學批評理論與實踐”

1958-劉劦思的創作論和批評論-一文心雕龍研究之二

1959-略談劉劦思的 “風骨” 論

一試談劉劦思論風骨

一關於 “風骨” 的解釋

一風骨的意義究竟是什麼?

1960-《文心雕龍》與劉劦思的世界觀

一劉劦《文心雕龍》的二元論哲學思想

一談劉劦《文心雕龍》的唯心主義本質

1961-《文心雕龍》選擇《定勢》郭晉稀

-《文心雕龍》選擇《風骨》郭晉稀 譯

-《文心雕龍》選擇《神思》郭晉稀

一《文心雕龍》選擇《體性》郭晉稀

一《文心雕龍》選擇《通變》郭晉稀

1962-《文心雕龍・比興》試譯趙仲邑

-《文心雕龍・風骨》試譯 趙仲邑

-《文心雕龍・誇飾》試譯 趙仲邑

-《文心雕龍・情采》試譯 趙仲邑

-《文心雕龍・熔裁》試譯 趙仲邑

-《文心雕龍・神思》試譯 趙仲邑

-《文心雕龍・體性》試譯 趙仲邑

一《文心雕龍・物色》試譯 趙仲邑

另外，此期間收錄的論文還包括劉劦思的創作理論、文體論、文質論以及他對文章風格的要 求等相關論文。

\section{三、從1976-1996年論文庫介紹}

此期間共收錄論文1860篇, 收錄的論文內容主要包括:

(一)、劉劦思的形象思維論、審美情感論、邏輯思想、寫作方法、時代風格等。

(二)、《文心雕龍》短論十篇、《文心雕龍校注拾遺》十篇、《文心雕龍》的十大貢獻兩 篇、臺灣《文心雕龍》研究成果相關論文十篇。

(三)、劉劦思與黑格爾的批評鑒賞論、劉劦與黑格爾藝術的起源與發展、劉劦與黑格爾 藝術產生的過程、實現的條件、劉劦思與黑格爾本質論之比較等十篇相關論文。 
（四）、《文心雕龍》辨疑《辨騷》八條、《才略》十三條、《風骨》九條、《樂府》八條等 十四篇相關論文。

(3) 1976-1996年部分年份論文數量統計表

\begin{tabular}{cccccccccc}
\hline 年份 & 1978 & 1979 & 1980 & 1982 & 1983 & 1985 & 1991 & 1993 & 1995 \\
\hline 數量 & 23 & 78 & 69 & 156 & 185 & 162 & 76 & 30 & 102 \\
\hline
\end{tabular}

\section{三、1997-2006年論文庫介紹}

此期間共收錄論文1413篇, 收錄的論文內容主要包括:

(一)、《文心雕龍譯注》50篇 王運熙

(二)、《文心雕龍》的體用之道、文化意蘊、主導思想等。

(三)、《駢體語譯文心雕龍》30篇＼cjkstart張光年譯述

(4) 1997-2006年部分年份論文數量統計表

\begin{tabular}{ccccccccc}
\hline 年份 & 1997 & 1998 & 1999 & 2001 & 2003 & 2004 & 2005 & 2006 \\
\hline 數量 & 60 & 130 & 78 & 146 & 128 & 188 & 202 & 28 \\
\hline
\end{tabular}

四、結語

以上就是對《文心雕龍》論文全文資料庫的簡要介紹, 《文心雕龍》是中華以至世界文庫 中的奇菂。在這裡感謝眾多專家、學者對《文心雕龍》論文全文資料庫的建設做出的卓越 貢獻, 正因為有他們的努力, 《文心雕龍》這一文論巨著才得以在劉劦思的故里綿延傳承。 